\title{
Recent Advances in Colorimetric Detection of Arsenic Using Metal-Based Nanoparticles
}

\author{
Haradhan Kolya ${ }^{1, *(\mathbb{D})}$, Kazuharu Hashitsume ${ }^{2}$ and Chun-Won Kang ${ }^{1, *(\mathbb{D})}$ \\ 1 Department of Housing Environmental Design and Research Institute of Human Ecology, College of Human \\ Ecology, Jeonbuk National University, Jeonju 54896, Jeonbuk, Korea \\ 2 Graduate Schools of Education, Shimane University 1060 Nishikawatsu-cho, Matsue, Shimane 690-8504, \\ Japan; hashitsume@edu.shimane-u.ac.jp \\ * Correspondence: haradhankoley@gmail.com (H.K.); kcwon@jbnu.ac.kr (C.-W.K.)
}

check for updates

Citation: Kolya, H.; Hashitsume, K.; Kang, C.-W. Recent Advances in Colorimetric Detection of Arsenic Using Metal-Based Nanoparticles. Toxics 2021, 9, 143. https://doi.org/ $10.3390 /$ toxics 9060143

Academic Editors: Rafael Clemente and Gregory Foster

Received: 15 April 2021

Accepted: 15 June 2021

Published: 17 June 2021

Publisher's Note: MDPI stays neutral with regard to jurisdictional claims in published maps and institutional affiliations.

Copyright: (c) 2021 by the authors. Licensee MDPI, Basel, Switzerland. This article is an open access article distributed under the terms and conditions of the Creative Commons Attribution (CC BY) license (https:/ / creativecommons.org/licenses/by/ $4.0 /)$.

\begin{abstract}
Nowadays, arsenic (III) contamination of drinking water is a global issue. Laboratory and instrument-based techniques are typically used to detect arsenic in water, with an accuracy of $1 \mathrm{ppb}$. However, such detection methods require a laboratory-based environment, skilled labor, and additional costs for setup. As a result, several metal-based nanoparticles have been studied to prepare a cost-effective and straightforward detector for arsenic (III) ions. Among the developed strategies, colorimetric detection is one of the simplest methods to detect arsenic (III) in water. Several portable digital detection technologies make nanoparticle-based colorimetric detectors useful for on-site arsenic detection. The present review showcases several metal-based nanoparticles that can detect arsenic (III) colorimetrically at a concentration of $\sim 0.12 \mathrm{ppb}$ or lower in water. A literature survey suggests that biomolecule-based metal nanoparticles could serve as low-cost, facile, susceptible, and eco-friendly alternatives for detecting arsenic (III). This review also describes future directions, perspectives and challenges in developing this alternative technology, which will help us reach a new milestone in designing an effective arsenic detector for commercial use.
\end{abstract}

Keywords: arsenic; nanoparticles; colorimetric detection; groundwater contamination; arsenicosis

\section{Introduction}

Globally, intake of arsenic (III) and arsenic (V) ions via food and drinking water has dramatically increased, as per several recent reports [1-8]. Approximately 200 million people worldwide are affected by arsenic toxicity [9]. According to the World Health Organization (WHO), arsenic in drinking water at a concentration of $>10 \mathrm{ppb}$ is highly unsafe to community health $[10,11]$. Arsenic comes to the groundwater surface via magmatism and periodic erosion [12-14]. In addition, several human activities are also responsible for raising the concentration of arsenic levels in groundwater. Industries that discharge effluents with arsenic into the soil or natural water resources include those involved in agrochemicals, pesticides, wood processes, and preservatives [15-17].

In general, inorganic arsenite and arsenate salts are naturally present in groundwater. A small amount of arsenic comes from organic compounds, such as dimethyl arsenic acid, dithioarsenate, and monomethyl arsenic acid [18,19]. Arsenic may present in four oxidation states, e.g., $-3,0,+3$, and +5 . Out of these, the trivalent and pentavalent forms of arsenic species are harmful to animals and plants $[20,21]$. The toxicity may vary with the type of exposure and oxidation state of arsenic. In particular, trivalent arsenic species are more toxic than pentavalent arsenic species [9,22]. Long-term arsenic exposure causes a variety of diseases, including arsenicosis, hemolysis, cancer, neurological disorders, and painful patches on the hands and feet $[20,23]$. Therefore, arsenic (III) concentrations in drinking water should be measured to avoid any harm to living organisms. Many detection methodologies have been adopted to measure arsenic levels in water steam, such as Raman spectroscopy (RS) [24], the fontal chromatography-ICP-MS method (FC-ICP-MS) [25], 
total reflection X-ray fluorescence (TXRF) spectrometry [26], Surface-enhanced Raman spectroscopy (SERS) [27], electrothermal atomic absorption spectrometry (ETAAS) [28], inductively coupled plasma mass spectroscopy (ICP-MS) [29], laser-induced breakdown spectroscopy (LIBS) [30], and atomic fluorescence spectroscopy (AFS) [31], all of which are sufficient to detect arsenic. In addition, chemisorbent resins provide a new approach to arsenic speciation [32]. However, these instrument-based strategies require a managed lab environment, a long operating time, trained labor, and pure chemicals [33].

Moreover, instruments that require electrical power and additional services have restricted use for on-site applications [34]. Therefore, a cheap and facile method, such as colorimetric detection of arsenic in water, can be an effective alternative. recent decades, researchers have explored metal nanoparticles (alone or in combination) based on colorimetric detectors to overcome the sensing system's drawbacks. Specifically, gold nanoparticles, silver nanoparticles, metal-organic frameworks $(\mathrm{MOFs})$, and metal graphene nanocomposites are extensively employed to fabricate arsenic sensors [35-42]. These colorimetric sensors can detect arsenic (III) ions efficiently in an aqueous medium. Metal nanostructures have excellent properties for the colorimetric determination of arsenic. However, these need significant improvement for practical applications.

Therefore, this review work investigates the recent developments in metal-based nanoparticles for the colorimetric detection of arsenic (III) in water. This review summarizes the sustainable, cost-effective and efficient strategies for arsenic sensing to realize these sensors in the real world.

\section{Arsenic and Its Harmful Effects}

An arsenic metalloid is one of the most naturally abundant metalloids, and it is also the most carcinogenic metalloid to living organisms. Its isotope has four oxidation states, from -3 to +5 . Water contamination with arsenic can occur through insecticides, industrial effluents, municipal sewage, and household waste [21,43]. A schematic representation of human exposure to arsenic is shown in Figure 1.

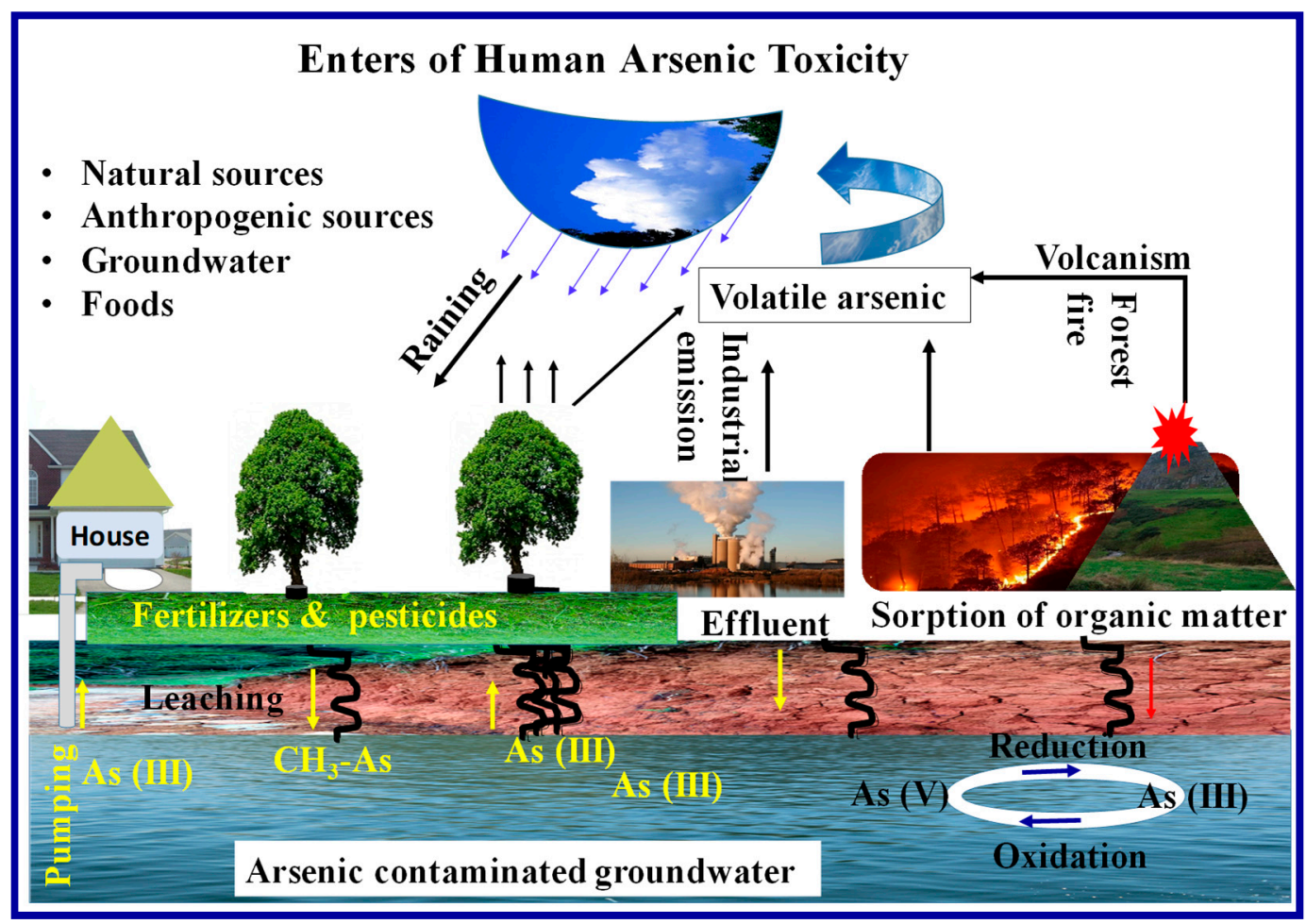

Figure 1. Schematic representation of human exposure to arsenic and arsenic cycle. 
Daily intake of arsenic-contaminated drinking water can create acute to chronic health impacts. Acute arsenic toxicity has been reported to cause acute paralytic syndrome (APS) and acute gastrointestinal syndrome (AGS) [44]. The central nervous system is depressed, and the cardiovascular system collapses in APS. Central nervous depression is caused by the necrosis of both white blood cells (WBCs) and red blood cells (RBCs) [45]. Arsenic (III) affects blood vessels, causing blood circulation problems and the sensation of pins and needles in the hands and feet [44]. AGS symptoms start with a taste of garlic, burning lips, dry mouth, and dysphagia [46]. Adsorption of arsenic by human beings for a longer time results in black-foot illnesses [47], lung cancer [48], and bladder cancer [49]. The symptoms are initially insidious in arsenicosis and based on the dose magnitude and exposure duration [50]. The exact mechanism of the occurrence of arsenicosis diseases in human organs is unclear. Arsenic biomethylation is crucial for the elucidation of its toxic and carcinogenic action. Arsenic transforms enzymatically into methyl arsenic $\left[\mathrm{CH}_{3}\right.$ $\left.\mathrm{AsO}_{2}{ }^{2-}\right]$ and dimethyl arsenic $\left[\left(\mathrm{CH}_{3}\right)_{2} \mathrm{AsO}_{2}{ }^{2-}\right]$ [51]. Arsenic can also cause genetic changes such as inhibition of DNA repair enzymes and changes in DNA methylation patterns [52].

Specific skin patches in pigmentation and keratosis are the common characteristics of chronic arsenic toxicity. Pigmentation may also involve mucous membranes such as the tongue under the surface or buccal mucous membranes [50]. Additionally, Leucomelanosis tends to occur in a patient with arsenicosis [53]. Numerous epidemiological studies have examined the risk of various cancers associated with arsenic absorption through drinking water. Many of these studies are ecological, and others suffer from methodological faults, particularly in exposure measurement [54]. However, there is significant evidence that greater arsenic levels in drinking water are linked to cancer growth in various locations, including the skin, bladder, and lungs. Arsenic-induced illness, including cancer, is a significant public health issue across the globe [54]. Hence, it is urgent to measure the concentration of arsenic in drinking water to identify arsenic-contaminated water. The identification followed by purification of arsenic-contaminated water can control the arsenicosis disease.

\section{Colorimetric Sensing of Arsenic}

In terms of ease of signal transduction, colorimetric analysis of arsenic has become the most practically applicable method. The Gutzeit method is one of the most commonly used methods for colorimetric analyses of arsenic. This method was employed to develop arsenic field test kits [55]. Although the Gutzeit method-based technique is economical, it produces toxic arsine gas as by-products. The molybdenum blue is also frequently used to detect arsenic in water samples. The molybdenum blue-based method is specific to arsenic (V); the interaction between arsenic $(\mathrm{V})$ and reduced molybdenum resulted in the appearance of the blue color [56]. Therefore, the molybdenum blue could differentiate arsenic (V) and arsenic (III).

Researchers explored metal nanostructure-based materials to make arsenic colorimetric sensors more sensitive, rapid, precise, economical, and efficient. Mainly, metal nanostructures-based sensors have been used to elaborate on a fundamental principle of color conversion, studied for colorimetric detection of arsenic solution [41]. This paper discusses the potential of metal-based nanoparticles for arsenic detection.

\subsection{Gold-Based Nanoparticles}

Scientists have focused extensively on developing gold nanoparticle (AuNP)-based sensors to detect arsenic in water samples. Recently, gold-modified lauryl sulfate nanoparticles with a limit of detection (LOD) of $2 \mathrm{ppb}$ were reported for colorimetric sensing of arsenic (III), using localized surface plasmon resonance (LSPR) [57]. The LSPR band shifted due to the color change of AuNPs-i.e., pink to blue-with arsenic (III) ions due to the interparticle coupling effect. Lauryl sulfate acts as a capping agent of AuNPs and is aggregated and replaced by the arsenic contaminant. The modification of AuNP surfaces with sulfurcontaining compounds is highly beneficial in enhancing AuNP-based colorimetric sensors' 
sensitivity; arsenic generally displays the intrinsic property of a potent binding affinity for sulfur-containing compounds. Therefore, glutathione (GSH), dithiothreitol (DTT), cysteine (Cys), and 2,6-pyridine dicarboxylic acid (PDCA) [GSH-DTT-CYs-PDCA]-functionalized AuNPs can detect arsenic (III) in water [58]. Arsenic (III) has a strong affinity for these ligands [59,60]. Arsenic (III) ions can interact with 3 DTT-conjugated gold nanoparticles through an As-S bond, as shown in Figure 2A-F [61]. However, there is no free SH group available for binding with arsenic (III) ions in the case of GSH- or Cys-conjugated gold nanoparticles. Figure 2G,H shows the colorimetric response of GSH/DTT/Cys-modified gold nanoparticles after the addition of arsenic (III) [61]. The addition of PDCA improved the test selectivity for arsenic (III) ions much more because PDCA could not interact with gold nanoparticles through the SH linkage in the same way as DTT, GSH, and Cys (Figure 2I,J) [61].
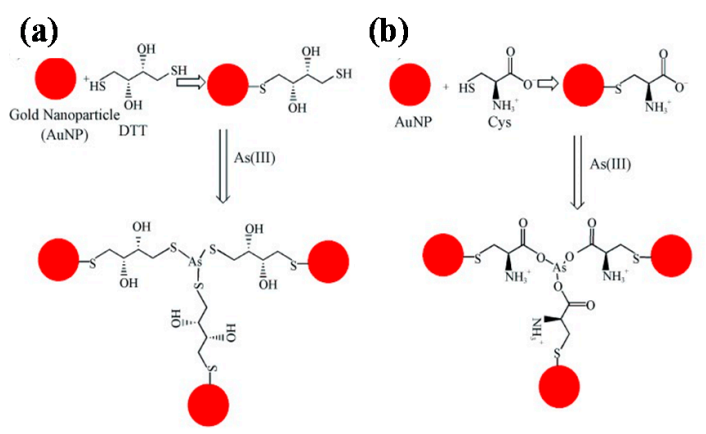

(c)

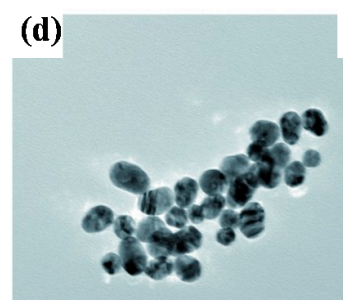

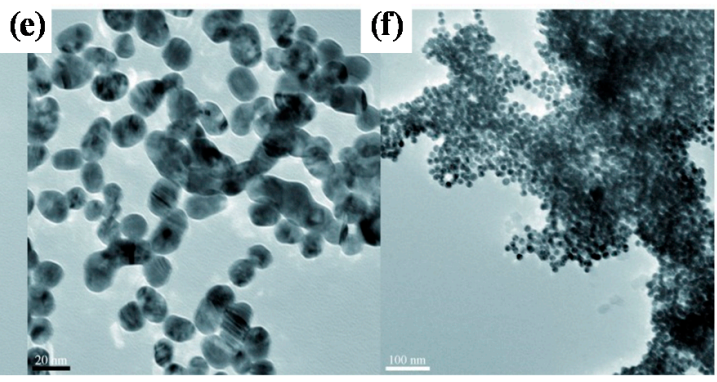

(g)

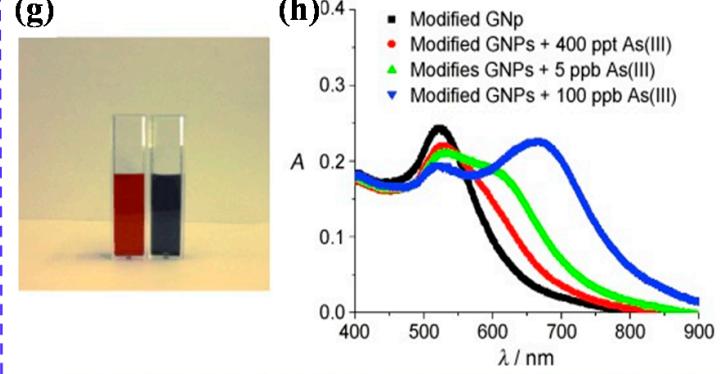

(i)

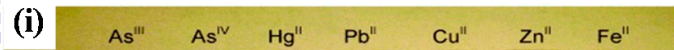

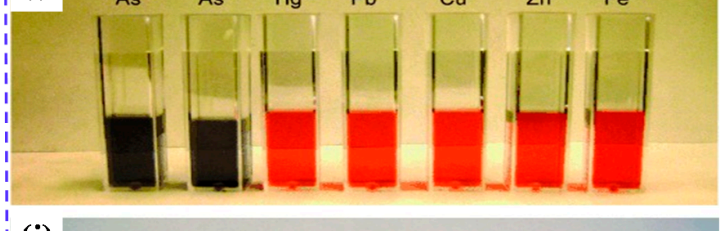

(j) $100 \mathrm{ppb} 10 \mathrm{ppb} \quad 1 \mathrm{ppb} \quad 100 \mathrm{ppt} 10 \mathrm{ppt}$

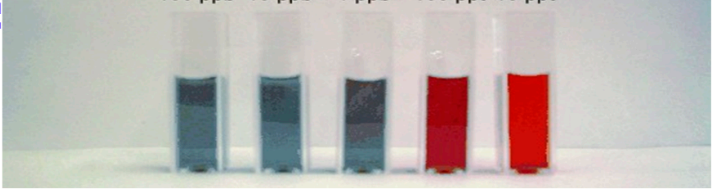

Figure 2. Representation of AuNP-based arsenic detection. (a) DTT-modified AuNPs; (b) Cys-modified AuNPs; (c) GSHmodified AuNPs; (d) TEM image showing GSH/DTT/Cys-modified AuNPs before the addition of arsenic (III); (e) TEM image demonstrating aggregation of GSH/DTT/Cys-modified AuNPs after addition of $80 \mathrm{ppb}$ arsenic (III); (f) TEM image after the addition of 250 ppt arsenic (III); (g) photograph showing colorimetric change of GSH/DTT/Cys-modified gold nanoparticles upon addition of 800 ppb arsenic (III); (h) absorption profiles of modified gold nanoparticles before and after addition of arsenic (III) ions; (i) photograph showing colorimetric changes of GSH/DTT/Cys-modified gold nanoparticles in the presence of PDCA upon addition of various metal ions (5 ppb) and (j) different concentrations of arsenic (III) [61]. Copyright 2009, reproduced with permission from WILEY-VCH Verlag GmbH \& Co. KGaA, Weinheim, Germany.

Moreover, it exhibited a LOD of $1 \mathrm{ppb}$, which is less than the allowable limit (as per Environmental Protection Agency (EPA) guidelines) of arsenic. Eco-friendly glucosefunctionalized gold nanoparticles are also sufficient for the colorimetric detection of arsenic (III) in water [41]. The glucose-functionalized AuNPs exhibited an LOD of $0.53 \mathrm{ppb}$. Hydroxyl groups of glucose interacted with gold particles and formed chemical bonds, stabilising gold nanoparticles and reducing the inter-particle distance among the nanoparticles. The color of nanoparticles changes depending on their inter-particle distance. Glucosefunctionalized gold nanoparticles showed a red color, but this changed sharply to blue with arsenic [41].

Moreover, citrate-capped gold nanoparticles showed a detection limit for arsenic (III) ions that was lower than $10 \mathrm{ppb}$ due to more interaction of citrates ion with arsenic (III) 
ions [62]. Additionally, Mangifera indica Leaf Extract mediated AuNPs can detect arsenic at a limit of $1.2 \mathrm{ppb}$ by the colorimetric detection technique. The leaf extract of the Mangifera indica acted as a reducing and stabilizing agent [63]. Encapsulation of gold Mangifera indica flower extract can detect arsenic (III) ions in water at optimum conditions [64]. Using LCMS/MS, the authors reported that Mangifera indica flower extract contains more mangiferin (977 ppb) than 3-hydroxy flavone (4 ppb). As shown in Figure 3, the theoretical study shows that the mangiferin and 3-hydroxy flavone present in Mangifera indica flower extract are responsible for detecting arsenic in aqueous media [64].
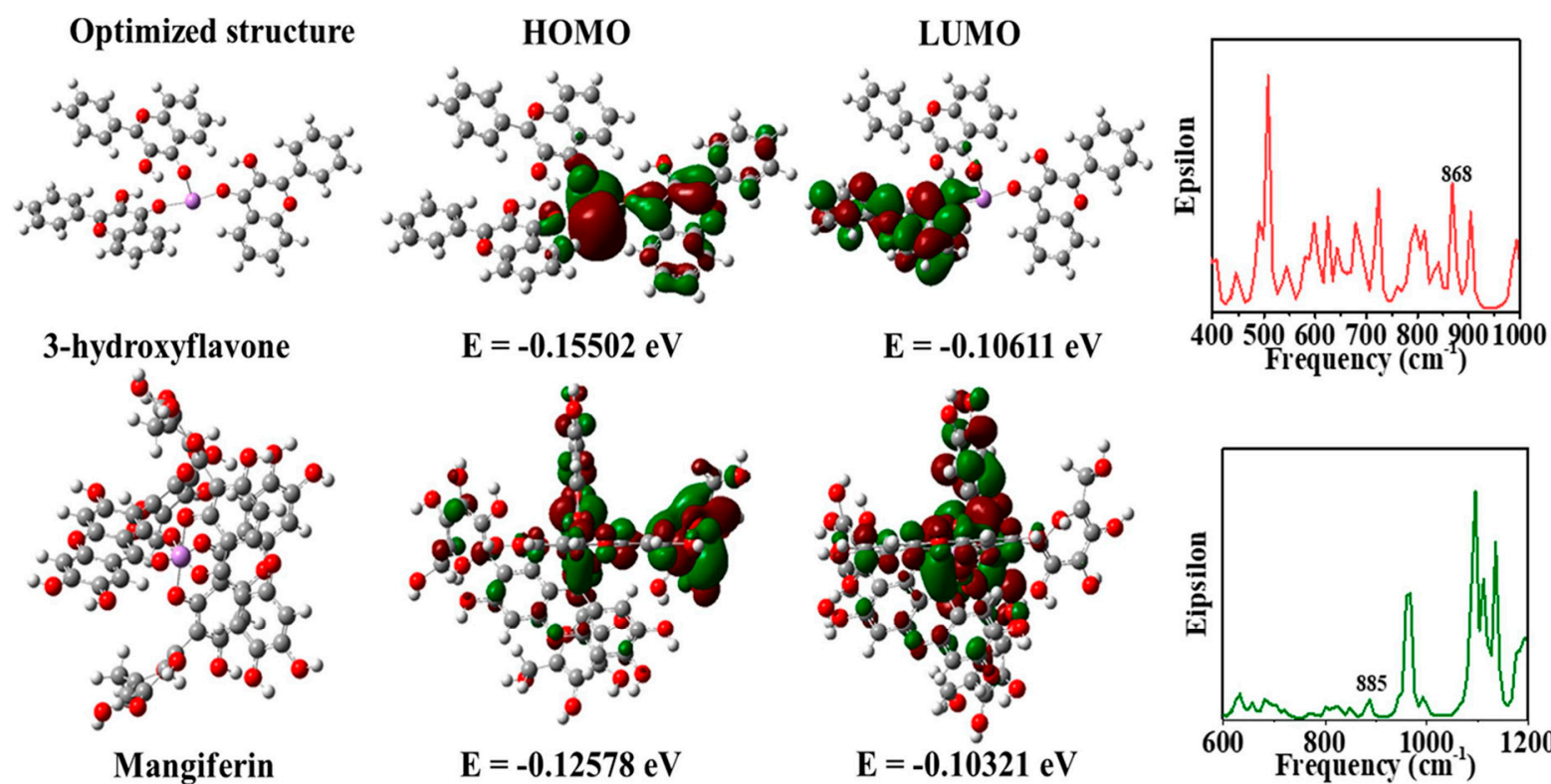

Frequency $\left(\mathrm{cm}^{-1}\right)$

Mangiferin

$\mathrm{E}=\mathbf{- 0 . 1 2 5 7 8 \mathrm { eV }}$

\begin{tabular}{|c|c|c|c|c|c|c|c|c|c|c|c|c|c|}
\hline \multicolumn{6}{|c|}{ Characteristics bond length (As-O) of optimized structures } & & \multicolumn{6}{|c|}{ Characteristic bond angles ( $\mathrm{O}-\mathrm{As}-\mathrm{O})$ of optimized structures } & \\
\hline & 1 & 2 & 3 & 4 & 5 & 6 & & 1 & 2 & 3 & 4 & 5 & \\
\hline & $20257 \AA$ & $87000 \AA$ & $1.87000 \AA$ & $1.20257 \AA$ & $1.20257 \AA$ & $1.87000 \AA$ & & $2.8756^{\circ}$ & $89.99997^{\circ}$ & $67.12438^{\circ}$ & $76.00248^{\circ}$ & $67.12439^{\circ}$ & $89.76723^{\circ}$ \\
\hline$(\mathbf{F L V}) 3$ & $2.61044 \AA$ & $1.92849 \AA$ & $1.94002 \AA$ & $\ldots$ & $\ldots$ & $\ldots$ & $\operatorname{As}(\mathbf{F L V}) 3$ & $170.43698^{\circ}$ & $86.36008^{\circ}$ & $84.11534^{\circ}$ & .. & $\ldots$ & \\
\hline
\end{tabular}

Figure 3. Images of theoretically optimized arsenic complexes with FLV (3-hydroxy flavone) and mangiferin (MI), highest occupied molecular orbital (HOMO), lowest unoccupied molecular orbital (LUMO), and a theoretical infrared (IR) spectrum [64]. Copyright 2020, reproduced with permission from Elsevier B.V., Amsterdam, The Netherlands.

However, glutathione-functionalized gold nanoparticles in RGB can carry out a fast colorimetric detection of arsenic (III) [65]. The detection limit of arsenic was $0.12 \mathrm{ppb}$, with a detection accuracy of around 2\%. As shown in Figure 4, GSH-functionalized AuNPs displayed excellent selectivity towards arsenic (III) ion in a water medium. Arsenic ions bind to GSH ligands, causing AuNP aggregation and a rapid color change in the solution [65].

\subsection{Silver-Based Nanoparticles}

Silver nanoparticles provide a rapid response to localized surface plasmon resonance compared to gold nanoparticles with enhanced sensitivity [66]. As in AuNPs, various capping agents have been exploited to construct silver nanoparticles for sensitive and selective sensing of arsenic. PEG-functionalized silver nanoparticles' are well-suited for detecting arsenic (III) ions in an aqueous medium [40]. The PEG-modified silver nanoparticles are sufficient enough to detect arsenic (III) in 1 ppb due to the addition of PEG. In addition, PEG-functionalized silver nanoparticles have adjustable negative surface charges, responsible for the stability of nanoparticles, and the electrostatic repulsion between negatively charged surfaces of silver nanoparticle protects them from accumulation. 

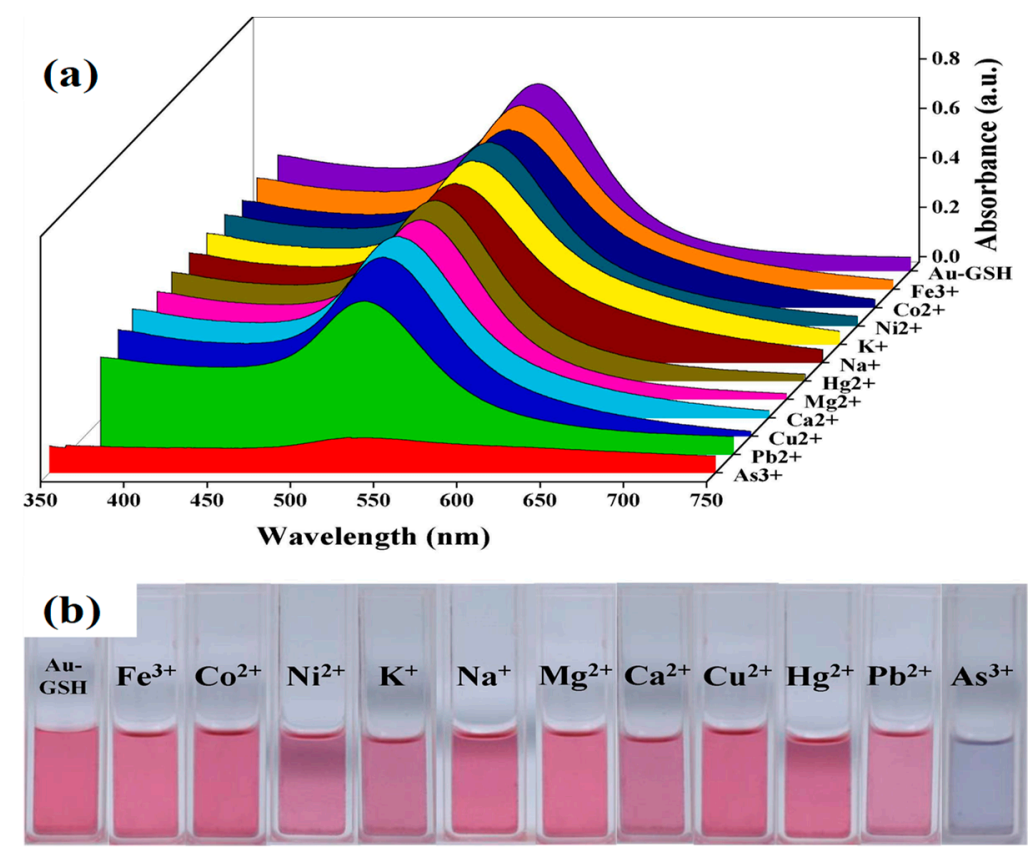

Figure 4. (a) Absorption spectra of GSH-AuNPs in the presence of different metallic ions and (b) the digital photograph of color changes of GSH-AuNPs in the presence of different metallic ions at a concentration of $10 \mathrm{ppb}$ and while arsenic (III) was 1 ppb [65]. Copyright 2020, reproduced with permission from Elsevier B.V., Amsterdam, The Netherlands.

Interestingly, in the presence of arsenic (III), these functional silver nanoparticles interacted with PEG hydroxyl groups, which led to the aggregation of silver nanoparticles [67]. As a result, the color of functionalized nanoparticles changed from yellow to bluish [40], as shown in Figure 5. Additionally, arsenic in Aptamer-AgNP solution remarkably decreases the absorbance peak due to the formation of the As-Aptamer-AgNPs complex. This testing method indicates highly selective detection of arsenic (III) ions with a LOD of $6 \mathrm{ppb}$ and a linear range of 50 to $700 \mathrm{ppb}$ [68].

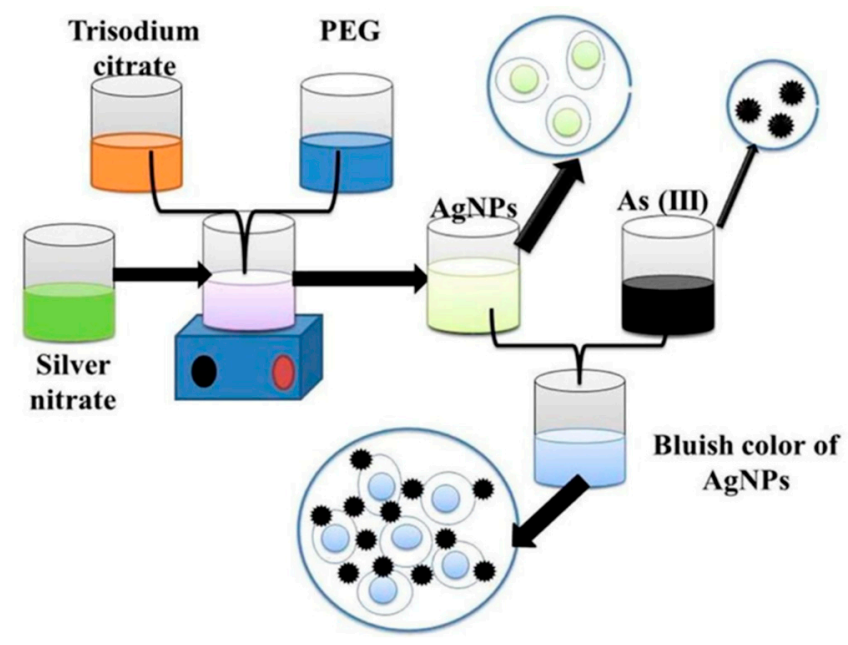

Figure 5. Functionalized silver nanoparticles as an effective medium towards trace determination of arsenic (III) in aqueous solution [40]. Copyright 2019, reproduced with permission from Elsevier B.V., Amsterdam, The Netherlands.

AgNPs functionalized with polyvinylpyrrolidone (PVP) have a significant affinity for arsenic (III) ions, as adding arsenic (III) ions to PVP-AgNP improved electrostatic interactions and morphological changes in nanoparticles. The UV-Vis spectra of AgNPs 
with different concentrations of arsenic (III) ions are shown in Figure 6 [69]. In addition, silver nanoplates (AgNPls) changed color quickly in the presence of arsenic (III) and arsenic (V). Ferrihydrite-coated silica gel has improved the selectivity of AgNPs towards arsenic (V) $\left(\mathrm{SiO}_{2}\right.$-Fh). The $\mathrm{AgNP}-\mathrm{SiO}_{2}$-Fh Acomposites can detect arsenic in concentrations ranging from 500 to $30000 \mathrm{ppb}$ [70].

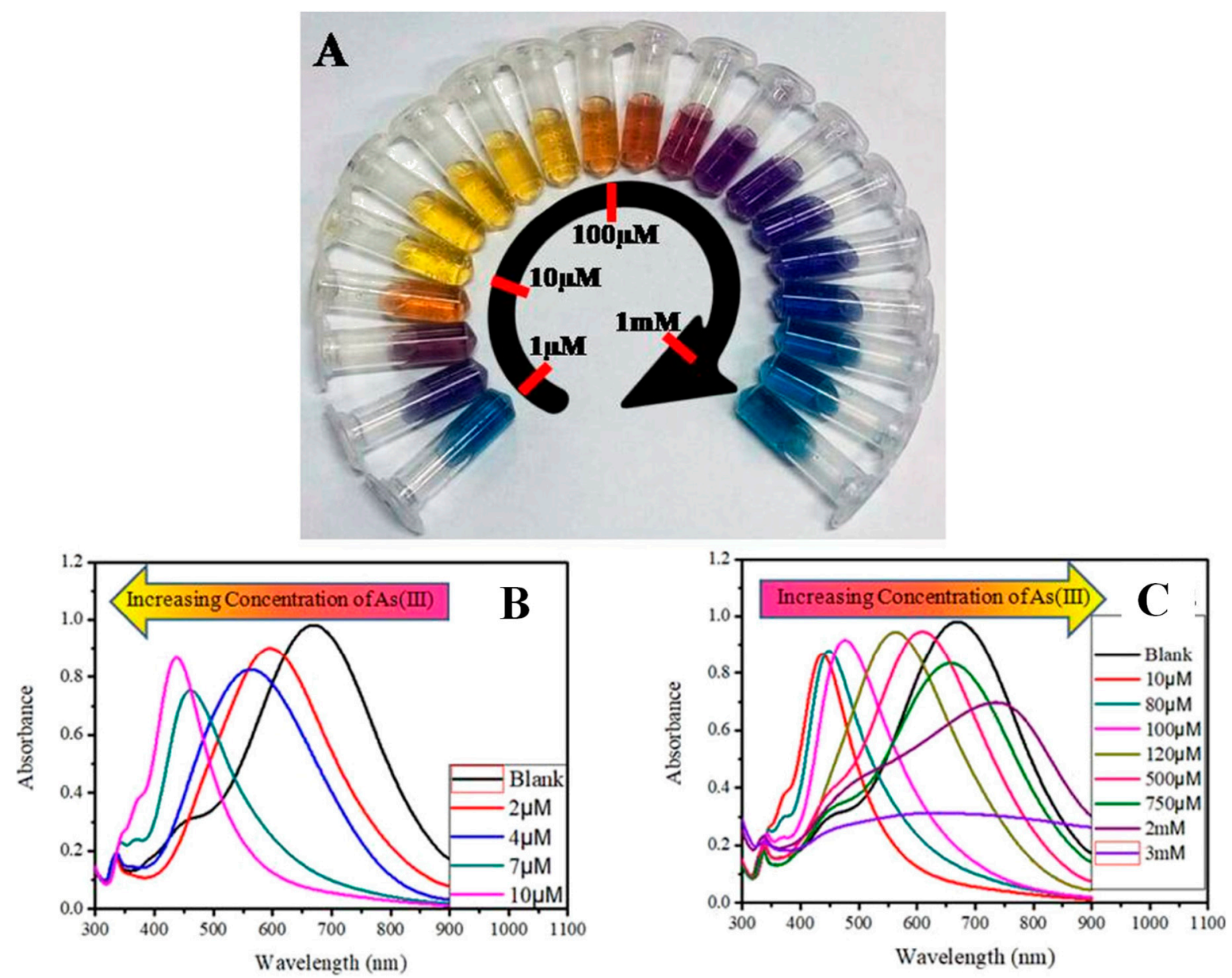

Figure 6. (A) Concentration-dependent color-coded sensing of arsenic (III) between the concentration range of $10^{-6}$ to $10^{-3} \mathrm{M},(\mathbf{B})$ tuning of SPR as a result of morphological change of AgNPr at different concentrations of arsenic (III) between $10^{-6}$ and $10^{-3} \mathrm{M}$ where (B) shows the variation of plasmon band at different lower concentrations of arsenic (III) in the range of $0.0-10.0 \mu \mathrm{M}(0.0 \mu \mathrm{M}$ (blank): black trace $(\lambda \max =704 \mathrm{~nm}), 1.0-2.0 \mu \mathrm{M}$ : blue trace, $2.0-4.0 \mu \mathrm{M}$ : orange trace, $5.0-7.0 \mu \mathrm{M}$ : red-violet trace, $8.0-10.0 \mu \mathrm{M}$ : blue-violet trace) and (C) at different higher concentrations of arsenic (III). The plasmon band, and hence the color of the nanomaterials, changes in a distinct manner, where a specific color remains unchanged in a broader range of growing concentrations such as: 10.0-80.0 $\mu \mathrm{M}$ : yellow, 90.0-100.0 $\mu \mathrm{M}$ : orange, 110.0-200.0 $\mu \mathrm{M}$ : dark red, 250.0-500.0 $\mu \mathrm{M}$ : purple, $750.0 \mu \mathrm{M}$ to $2 \mathrm{mM}$ : different shades of blue, 3-10 mM: faded blue, and above $10 \mathrm{mM}$ the color becomes faint blue to grey or almost colorless [69]. Copyright 2019, reproduced with permission from American Chemical Society, Washington, DC, USA.

Recently, multi-ligand-based AgNPs were studied to detect arsenic (III) using the colorimetric approach. It could be synthesized by the chemical reduction method using asparagine (Asn) as the capping agent and further alteration with reduced GSH and DTT. The synthesized GSH/DTT/Asn-AgNPs could be used as multifunctional probes for an multimodal arsenic assay (III) due to their outstanding plasmonic properties and characteristic electrochemical activity. This approach can detect arsenic even at a low concentration of $0.36 \mathrm{ppb}$ [71]. 


\subsection{Metal Oxide-Based Nanoparticles}

Nanostructured transition metal oxides such as $\mathrm{Fe}_{3} \mathrm{O}_{4}, \mathrm{MgO}, \mathrm{TiO}_{2}, \mathrm{ZnO}, \mathrm{NiO}, \mathrm{SnO}_{2}$, $\mathrm{CeO}_{2}, \mathrm{MnO}_{2}, \mathrm{ZrO}_{4}$, and $\mathrm{NiWO}_{4}$ are used for heavy metal sensing. Transition metals are usually economical, highly conductive, suitable adsorbents and highly stable [72]. Therefore, metal nanoparticles displayed excellent performances for the detection of arsenic (III) ions in water. For example, $\mathrm{Fe}_{3} \mathrm{O}_{4}$ nanoparticles bonded with gold ligands exhibited excellent selectivity and quick visual detection of arsenic. The $\mathrm{Fe}_{3} \mathrm{O}_{4} @ \mathrm{Au}$-based colorimetric system exhibited a LOD of $0.86 \mathrm{ppb}$ for arsenic (III) detection [73]. In another report, $\alpha-\mathrm{Fe}_{2} \mathrm{O}_{3}$ was prepared from a waste banana peel extract because banana peel contains excessive polyphenols and flavonoids that act as reducing agents. Almost similar size $(60 \mathrm{~nm})$ nanoparticles were used to simultaneously detect and adsorb arsenic (V). The $\alpha-\mathrm{Fe}_{2} \mathrm{O}_{3}$-based colorimetric sensor exhibited a LOD of $100 \mathrm{ppb}$ for arsenic (V) [74]. The positive charge of nanoparticles facilitated the high adsorption of negatively charged arsenate ions due to electrostatic interaction. A schematic of the synthesis of $\alpha-\mathrm{Fe}_{2} \mathrm{O}_{3}$ and its application in detecting arsenic (V) is shown in Figure 7 [74].

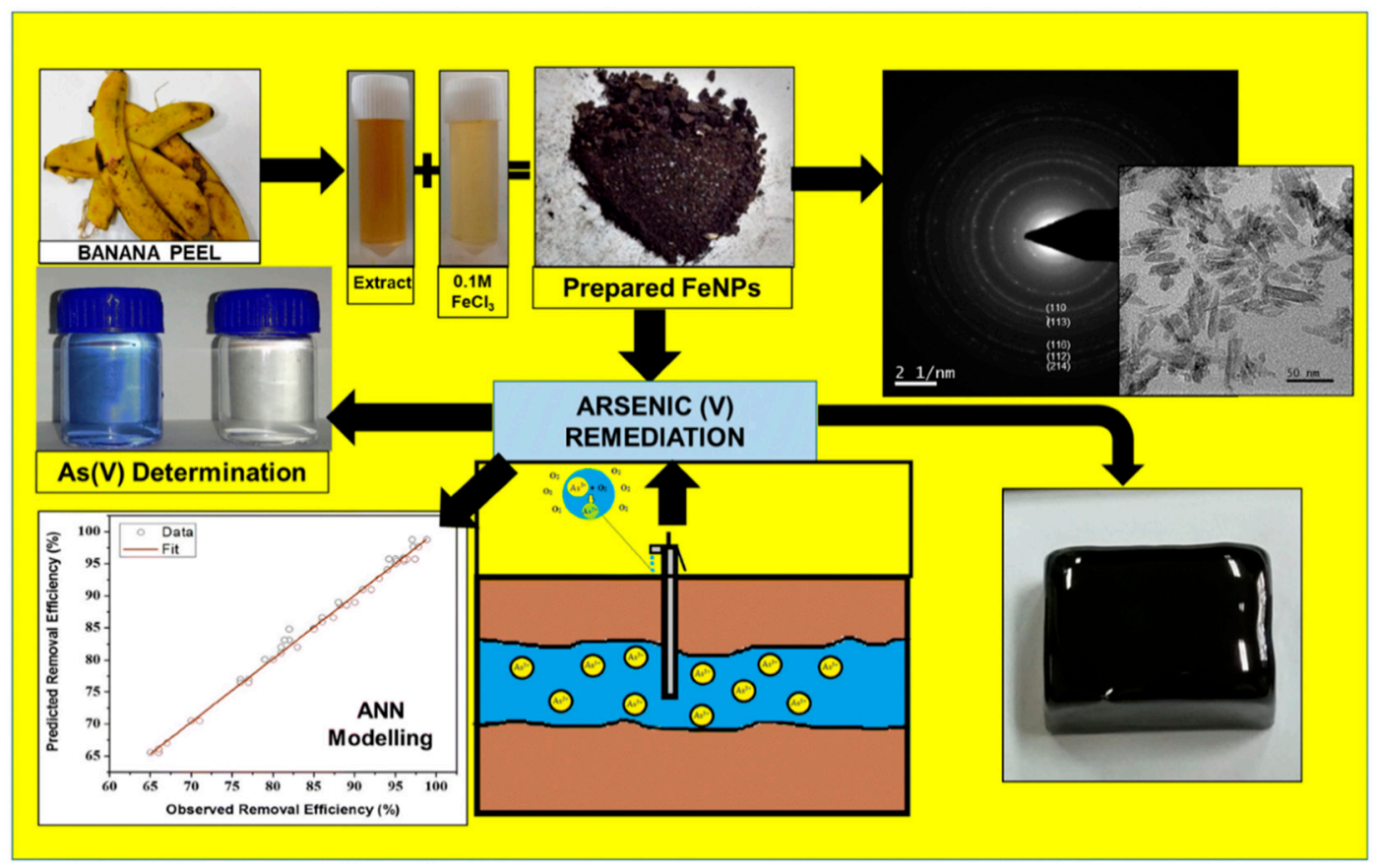

Figure 7. A schematic representation of the synthesis of $\mathrm{Fe}_{3} \mathrm{O}_{4}$ and detection of arsenic [74]. Copyright 2019, reproduced with permission from Springer-Verlag $\mathrm{GmbH}$, Heidelberg, Germany.

DNA-functionalized $\mathrm{Fe}_{3} \mathrm{O}_{4}$ nanoparticles showed significant affinity and selectivity towards arsenic and could be used to detect arsenic in water up to $0.95 \mathrm{ppb}$ by the fluorescence quenching technique [75]. Furthermore, other nanoparticles, e.g., $\mathrm{CeO}_{2}$ nanoparticles, were modified with DNA to investigate arsenic levels [76]. The desorption of DNA from nanomaterials is caused by interactions between DNA-conjugated nanostructures and arsenic. The results showed that $\mathrm{CeO}_{2}$ nanoparticles had improved performances compared to $\mathrm{Fe}_{3} \mathrm{O}_{4}$, with the LOD nearly 10 -fold less than $\mathrm{Fe}_{3} \mathrm{O}_{4}$ [76]. A novel CuInS 2 quantum dots@magnetic $\mathrm{Fe}_{3} \mathrm{O}_{4}$ nanocomposite-based "turn off" nanosensor for arsenic detection was revealed. The CuInS 2 quantum dots@magnetic $\mathrm{Fe}_{3} \mathrm{O}_{4}$ was able to detect at as low as $10 \mathrm{ppb}$ [77]. A schematic illustration of the fabrication of $\mathrm{CuInS}_{2}$ quantum dots@magnetic $\mathrm{Fe}_{3} \mathrm{O}_{4}$ is shown in Figure 8. 
(A)

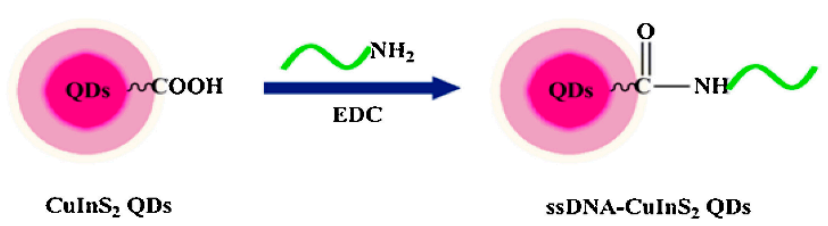

(B)
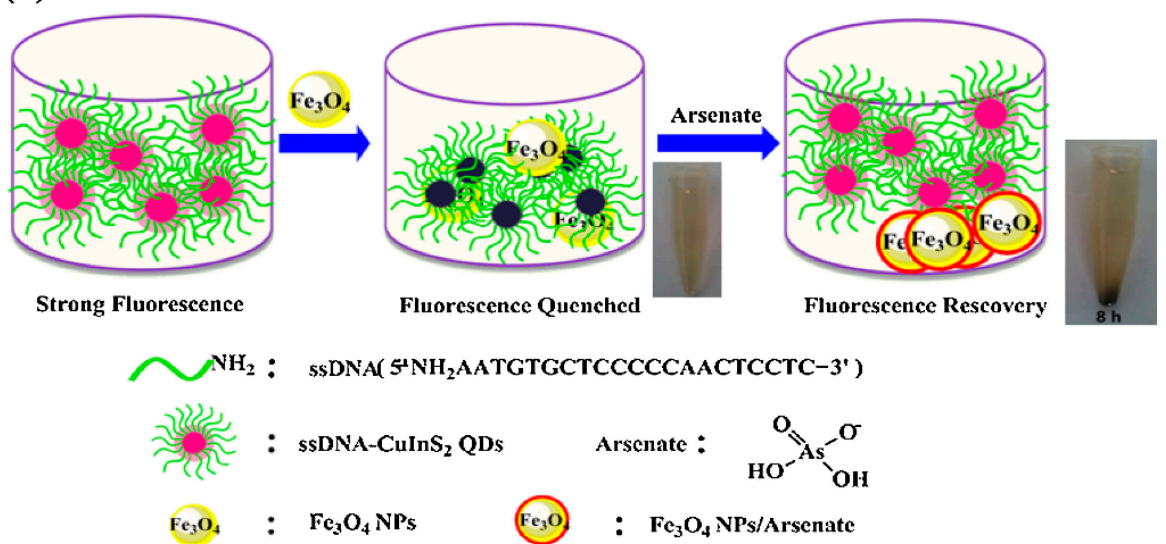

(C)

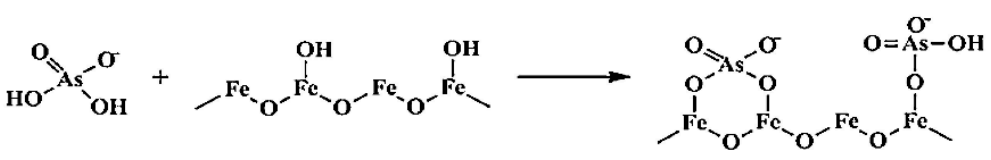

Figure 8. (A) Schematic illustration for the fabrication of ssDNA-CuInS 2 QDs. (B) The schematic illustration of sensing arsenate by ssDNA-CuInS2 QDs@Fe $\mathrm{O}_{4}$ NPs and the arsenate removal photographs by a magnet. (C) Schematic illustration of the mechanism of arsenate adsorption onto $\mathrm{Fe}_{3} \mathrm{O}_{4}$ NPs [77]. Copyright 2015, reproduced with permission from Elsevier B.V., Amsterdam, The Netherlands.

Cobalt oxyhydroxide $(\mathrm{CoOOH})$ nanoflakes showed significant arsenic detection efficiency in addition to iron oxide [78]. $\mathrm{CoOOH}$ nanoflakes show peroxidase-like activity, which produces a green-colored oxidation product in the presence of $\mathrm{H}_{2} \mathrm{O}_{2}$ and 2,2'azinobis (3-ethylbenzothiazoline-6-sulfonic acid) (ABTS). Interestingly, the green color was not observed in the presence of arsenic, as arsenic binds with $\mathrm{CoOOH}$ through electrostatic attraction and forms an As-O bond to inhibit peroxidase-like activity. Therefore, it can effectively detect arsenic in water using the colorimetric method with a LOD of $3.72 \mathrm{ppb}[78]$.

\subsection{Metal GO- or CNT-Based Nanoparticles}

A variety of nano-scale carbon-based building blocks, including nanotubes, graphene and graphene oxide, have drawn significant interest as electrode materials for detection of heavy metals owing to their extraordinary physical and chemical properties, i.e., elevated surface area, high electrical conductivity, powerful mechanical strength, biocompatibility and low manufacturing costs $[79,80]$. Graphene oxide (GO) has a two-dimensional plane and many functional groups containing oxygen with the disorder on the basal planes and edges. The GO develop significant mechanical properties and chemical sensing activity [81]. Recently, a magnetic graphene quantum dot-based sensor (fluorescence probe) was reported as a highly sensitive and arsenic-selective material [82]. The fluorescent zinc oxide and CdS quantum dots (QDs) were revealed as arsenic sensor components by fluorescence spectroscopy $[83,84]$. A magnetic graphene quantum dot-based sensor yielded better outcomes than $\mathrm{ZnO}$ (QDs) and CDS (QDs) due to the presence of iron oxide, which offered more contact for the formation of the chelating complex with arsenic in the medium [82]. A research group has recently reported a highly selective and sensitive and cost-effective prism-based SPR sensor integrated with a hydrous ferric oxide- 
magnetite-reduced graphene oxide nanocomposite to detect arsenic ions at a detection limit of $0.1 \mathrm{ppb}$ [85].

\subsection{Metal-Organic Framework}

The MOFs are essential in separation, drug delivery and catalysis fields [86]. The MOF shows the attractive hybrid characteristic of organic bridging ligands and metal particulates in a framework that displays a larger surface area [87]. The large surface area of MOFs offers multiple channels for guest molecules to enter and interact with the framework. This phenomenon is quite helpful for trapping targeted pollutants effectively and fulfils the requirement of detection and removal of contaminates. The intrinsic open pore structure and extensive channels can encourage the quick diffusion and transportation of targeted pollutants, thus ensuring a rapid response time, selective detection and fast kinetics [88]. Hence, MOF materials are becoming promising candidates for sensing and removing arsenic simultaneously [89]. Several recent studies have shown MOFs' proper function and composites to detect and remove arsenic [90,91]. Figure 9 illustrates a modification of MOFs to coordinate arsenic (V) moieties at the node [90]. Therefore, amino-decorated MOF products are interesting.

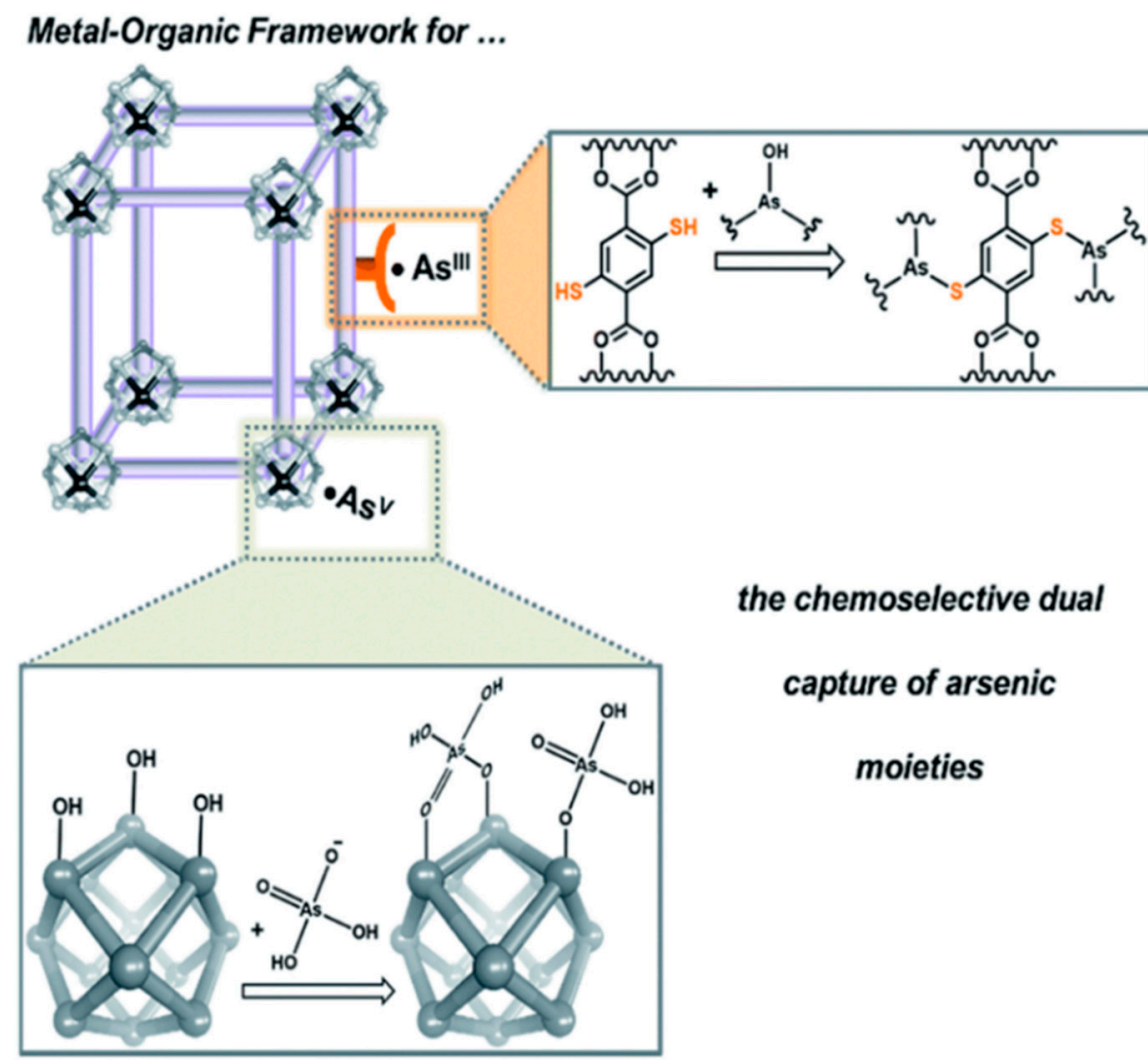

Figure 9. A schematic illustration illustrating how MOFs can be tailored to coordinate anionic arsenic (V) moieties at the node while binding neutral arsenic (III) to the framework [90]. Copyright 2016, reproduced with permission from Royal Society of Chemistry, London, U.K.

The amino-functionalized iron-based MOFs showed good selectivity for arsenic (III) identification. The most frequently observed MOF structure warped after coming into contact with water. High-valance metal ions such as $\mathrm{Cr}$ (III), Zr (IV), Fe (III), and Al (III) were used to build chemically stable coordination bonds to improve the water stability of ligand-based carboxylate MOF. The introduction of ligands with hydrophobic functionality such as methyl, ethyl, and trifluoromethyl is important to protect metal bodies from hydrolysis [92,93]. Therefore, two organic tritopic carboxylic acids with methyl and ethyl groups, dimethyl-5'-(4(methoxycarbonyl)phenyl)-2', 4', $6^{\prime}$-trimethyl-[1, $1^{\prime}: 3^{\prime}, 1^{\prime \prime}$-terphenyl]- 
4, $4^{\prime \prime}$-dicarboxylic acid (H3CTTA) and dimethyl-2', $4^{\prime}, 6^{\prime}$-triethyl-5'-(4-(methoxycarbonyl) phenyl)-[1,1',3', $1^{\prime \prime}$-terphenyl] $-4,4^{\prime \prime}$-dicarboxylic acid (H3CETA) were synthesized. Then, both H3CTTA and H3CETA were reacted with aluminium nitrate in DMF solvent, respectively. The materials derived from this reaction were observed to be extremely porous and labeled Al-MOF (CTTA) and Al-MOF (CETA). Al-MOF (CTTA) exhibited an improved detection efficiency to arsenic (III) from roxarsone (ROX) and nitrosone (NIT) [92].

The above information has been summarized in Table 1 to compare the colorimetric detection performances of nanoparticles.

Table 1. The LOD of arsenic (III) using various nanoparticles and a colorimetric approach.

\begin{tabular}{|c|c|c|c|c|}
\hline No & Metal Nanoparticles & $\begin{array}{c}\text { Limit of } \\
\text { Detection (ppb) }\end{array}$ & $\begin{array}{c}\text { Range of } \\
\text { Detection (ppb) }\end{array}$ & Reference \\
\hline 1. & S-layer protein-AuNPs & 240 & $240-2400$ & [37] \\
\hline 2. & Glucose-AuNPs & 0.53 & $1-14$ & [41] \\
\hline 3. & AuNPs-lauryl sulfate & 2.0 & $5-500$ & [57] \\
\hline 4. & GSH-DTT-CYs-PDCA-AuNPs & 2.5 & $2-20$ & [58] \\
\hline 5. & Glutathione + AuNPs & 0.003 & n.a. & {$[61]$} \\
\hline 6. & AuNPs-PEG & 5.0 & n.a. & [94] \\
\hline 7. & Aptamer-based AuNPs & 1.26 & $1.26-200$ & [95] \\
\hline 8. & Aptamers-AuNPs-surfactant & 0.6 & $1-1500$ & [96] \\
\hline 9. & Citrate-capped AuNPs & 1.8 & $4-100$ & {$[62]$} \\
\hline 10. & Mangifera indica leaf extract-AuNPs & 1.2 & n.a. & {$[63]$} \\
\hline 11. & GSH-functionalized AuNPs & 0.12 & n.a. & {$[65]$} \\
\hline 12. & ssDNA-AuNPs & 0.18 & $1-30$ & [97] \\
\hline 13. & Aptamer-CTAB-AuNPs & 16.9 & $1-100$ & [98] \\
\hline 14. & AuNPs DNA aptamer & 161 & $76.6-766$ & [99] \\
\hline 15. & DMSA-Au nanorod & 1.0 & n.a. & {$[100]$} \\
\hline 16. & DTT-AuNRs & 10 & $10-100.1$ & [101] \\
\hline 17. & Europium-AuNPs & 10 & n.a. & {$[102]$} \\
\hline 18. & Au-cationic polymer and aptamer & 5.3 & n.a. & {$[103]$} \\
\hline 19. & Peptide-AuNPs & 1.5 & n.a. & {$[104]$} \\
\hline 20. & Thioctic acid-thioguanine-AuNPs & 1.0 & n.a. & {$[105]$} \\
\hline 21. & Asparagine-AuNPs & 100 & 100-2000 & {$[106]$} \\
\hline 22. & Sucrose-AuNPs & 20 & $50-3000$ & {$[107]$} \\
\hline 23. & PEG-AgNPs & 1.0 & $5-13$ & {$[40]$} \\
\hline 24. & Aptamer-AgNPs & 6.0 & $50-700$ & {$[68]$} \\
\hline 25. & $\mathrm{AgNPls}-\mathrm{SiO}_{2}-\mathrm{Fh}$ & 500 & $500-3000$ & {$[70]$} \\
\hline 26. & AgNPls-SiO $2-F h$ & 500 & $500-30,000$ & {$[70]$} \\
\hline 27. & GSH/DTT/Asn-AgNPs & 0.36 & $0.4-20$ & [71] \\
\hline 28. & $\mathrm{Fe}_{3} \mathrm{O}_{4}$ (core)-gold (shell)-thiol ligands & 0.86 & n.a. & {$[73]$} \\
\hline 29. & $\alpha-\mathrm{Fe}_{2} \mathrm{O}_{3}$ & 100 & $100-2000$ & {$[74]$} \\
\hline 30. & DNA-functionalized $\mathrm{Fe}_{3} \mathrm{O}_{4}$ nanoparticles & 0.95 & n.a. & [75] \\
\hline 31. & CuInS 2 quantum dots@magnetic $\mathrm{Fe}_{3} \mathrm{O}_{4}$ & 10 & $0.015-15384.6$ & {$[77]$} \\
\hline 32. & Cobalt oxyhydroxide $(\mathrm{CoOOH})$ nanoflakes & 3.72 & $4-500$ & {$[78]$} \\
\hline 33. & Zinc oxide modified with curcumin & 100 & $100-3000$ & {$[108]$} \\
\hline 34. & Oxidase-mimicking activity of $\mathrm{Mn}_{3} \mathrm{O}_{4} \mathrm{NPs}$ & 1320 & $5000-100,000$ & {$[109]$} \\
\hline 35. & Dithiothreitol-capped Pd nanoparticles & 3.5 & $3.3-333,330$ & {$[110]$} \\
\hline 36. & Hemin- $\mathrm{H}_{2} \mathrm{O}_{2}$ & 6 & $10-200$ & {$[111]$} \\
\hline 37. & L-arginine-modified FeOOH & 420 & $670-3,333,330$ & {$[112]$} \\
\hline
\end{tabular}

n.a. @ represents core and shell.

\subsection{Future Directions, Perspectives and Challenges}

Despite the recent advances in this area, there are still many issues to be addressed. 
(1) $\mathrm{pH}$ and temperature are significant for detecting arsenic (III) ions in water. There are only a few colorimetric methods for detecting arsenic (III) with the variation of temperature and $\mathrm{pH}$. Therefore, the development of new nanomaterials would support their practical applications.

(2) Although some reported nanomaterials have good sensitivity, they are often affected by other metal ions found in groundwater. Therefore, research and development on the sensitivity of nanomaterials should be sufficient to detect arsenic in other situations that are also of great interest.

(3) Some biomolecule-based nanoparticles have higher sensitivities, but they are challenging to use in practice due to the reproducibility of steady-size nanoparticles. Since the size of the nanoparticles is the key in the detection of arsenic (III), research and development on repeated synthesis with regular-sized nanoparticles is still of the utmost importance.

(4) Further research on arsenic (III) detection using metal nanoparticles will be necessary to enhance practical application.

(5) Nanoparticles should be designed to be low-cost, simple to use, environmentally friendly, and have practical applicability accessible to the general public.

Future research in this field should focus on developing novel highly selective and sensitive nanoparticles for colorimetric detection of arsenic that are simple to use, antiinterference, fast, have a low detection limit and environmentally friendly.

\section{Conclusions}

This review highlights metal nanoparticles' progress for detecting arsenic in aqueous media by colorimetric techniques. Compared to other techniques, the colorimetric methods covered in the present review showed better sensing efficiency. Here, we discussed the colorimetric detection of arsenic (III) in comparison to AuNPS, AgNPs, metal oxide nanoparticles, metal GO or CNT-based materials, and metal-organic frameworks. We found that colorimetric methods for detecting arsenic with various AuNPs were appealing. This paper could help to develop new nanomaterials for colorimetric detection of arsenic (III).

Author Contributions: H.K.: conceptualization, writing—original draft, and writing-review and editing. K.H.: writing-review and editing. C.-W.K.: project administration, funding acquisition, and writing-review and editing. All authors have read and agreed to the published version of the manuscript.

Funding: This research was supported by Basic Science Research Program through the National Research Foundation (NRF) of Korea, funded by the Ministry of Education (NRF-2019R1I1A3A02059471), and was supported under the framework of International Co-operation program managed by the NRF of Korea (NRF-2020K2A9A2A08000181).

Institutional Review Board Statement: Not applicable.

Informed Consent Statement: Not applicable.

Data Availability Statement: Not applicable.

Conflicts of Interest: The authors declare that they have no known competing financial interests or personal relationships that could have appeared to influence the work reported in this paper.

\section{Abbreviations}

$\begin{array}{ll}\text { AFS } & \text { Atomic Fluorescence Spectroscopy } \\ \text { AgNPls } & \text { Silver Nanoplates } \\ \text { AgNPs } & \text { Silver Nanoparticles } \\ \text { AGS } & \text { Acute Gastrointestinal Syndrome } \\ \text { APS } & \text { Acute Paralytic Syndrome } \\ \text { AuNPs } & \text { Gold Nanoparticles } \\ \text { CNT } & \text { Carbon Nanotube }\end{array}$




$\begin{array}{ll}\text { Cys } & \text { Cysteine } \\ \text { LOD } & \text { Limit of detection } \\ \text { DMSA } & \text { Meso-2,3-Dimercaptosuccinic Acid } \\ \text { DNA } & \text { Deoxyribose Nucleic Acid } \\ \text { DTT } & \text { Dithiothreitol } \\ \text { EPA } & \text { Environmental Protection Agency } \\ \text { ETAAS } & \text { Electrothermal atomic absorption spectrometry } \\ \text { GO } & \text { Graphene Oxide } \\ \text { GSH } & \text { Glutathione } \\ \text { ICP-MS } & \text { Inductively Coupled Plasma Mass Spectroscopy } \\ \text { LIBS } & \text { Laser-Induced Breakdown Spectroscopy } \\ \text { LSPR } & \text { Localized Surface Plasmon Resonance } \\ \text { MOF } & \text { Metal-Organic Framework } \\ \text { PDCA } & \text { Pyridine Dicarboxylic Acid } \\ \text { PEG } & \text { Polyethylene Glycol } \\ \text { ppb } & \text { Parts Per Billion } \\ \text { PVP } & \text { Polyvinylpyrrolidone } \\ \text { QDs } & \text { Quantum Dots } \\ \text { RBC } & \text { Red Blood Cell } \\ \text { RS } & \text { Raman Spectroscopy } \\ \text { WBC } & \text { White Blood Cell }\end{array}$

\section{References}

1. Rodríguez-Lado, L.; Sun, G.; Berg, M.; Zhang, Q.; Xue, H.; Zheng, Q.; Johnson, C.A. Groundwater Arsenic Contamination Throughout China. Science 2013, 341, 866-868. [CrossRef] [PubMed]

2. Agusa, T.; Trang, P.T.K.; Lan, V.M.; Anh, D.H.; Tanabe, S.; Viet, P.H.; Berg, M. Human exposure to arsenic from drinking water in Vietnam. Sci. Total. Environ. 2014, 488-489, 562-569. [CrossRef] [PubMed]

3. Williams, P.N.; Raab, A.; Feldmann, J.; Meharg, A.A. Market Basket Survey Shows Elevated Levels of As in South Central U.S. Processed Rice Compared to California: Consequences for Human Dietary Exposure. Environ. Sci. Technol. 2007, 41, 2178-2183. [CrossRef]

4. Khan, K.M.; Parvez, F.; Zoeller, R.T.; Hocevar, B.A.; Kamendulis, L.M.; Rohlman, D.; Eunus, M.; Graziano, J. Thyroid hormones and neurobehavioral functions among adolescents chronically exposed to groundwater with geogenic arsenic in Bangladesh. Sci. Total. Environ. 2019, 678, 278-287. [CrossRef] [PubMed]

5. Upadhyay, M.; Majumdar, A.; Barla, A.; Bose, S.; Srivastava, S. An assessment of arsenic hazard in groundwater-soil-rice system in two villages of Nadia district, West Bengal, India. Environ. Geochem. Health 2019, 41, 2381-2395. [CrossRef]

6. Palmer, M.J.; Chételat, J.; Richardson, M.; Jamieson, H.E.; Galloway, J. Seasonal variation of arsenic and antimony in surface waters of small subarctic lakes impacted by legacy mining pollution near Yellowknife, NT, Canada. Sci. Total. Environ. 2019, 684, 326-339. [CrossRef]

7. Dhillon, A.K. Arsenic Contamination of India's Groundwater: A Review and Critical Analysis BT. In Arsenic Water Resources Contamination: Challenges and Solutions; Fares, A., Singh, S.K., Eds.; Springer: Cham, Switzerland, 2020; pp. 177-205. ISBN 9783030212582.

8. Pincetti-Zúniga, G.P.; Richards, L.A.; Tun, Y.M.; Aung, H.P.; Swar, A.K.; Reh, U.P.; Khaing, T.; Hlaing, M.M.; Myint, T.A.; Nwe, M.L.; et al. Major and trace (including arsenic) groundwater chemistry in central and southern Myanmar. Appl. Geochem. 2020, 115, 104535. [CrossRef]

9. Coryell, M.; McAlpine, M.; Pinkham, N.V.; McDermott, T.R.; Walk, S.T. The gut microbiome is required for full protection against acute arsenic toxicity in mouse models. Nat. Commun. 2018, 9, 1-9. [CrossRef]

10. Buttner, M.M.; Bormann, J.E.; Weingart, K.; Andrews, T.; Ferguson, M.; Afari, N.; Information, P.E.K.F.C. Multi-site evaluation of a complementary, spiritually-based intervention for Veterans: The Mantram Repetition Program. Complement. Ther. Clin. Pr. 2016, 22, 74-79. [CrossRef]

11. Ahmad, A.; Bhattacharya, P. Arsenic in Drinking Water: Is $10 \mu \mathrm{g} / \mathrm{L}$ a Safe Limit? Curr. Pollut. Rep. 2019, 5, 1-3. [CrossRef]

12. Ponthieu, M.; Pinel-Raffaitin, P.; Le Hécho, I.; Mazéas, L.; Amouroux, D.; Donard, O.F.; Potin-Gautier, M. Speciation analysis of arsenic in landfill leachate. Water Res. 2007, 41, 3177-3185. [CrossRef]

13. Gamboa-Loira, B.; Cebrián, M.E.; Franco-Marina, F.; López-Carrillo, L. Arsenic metabolism and cancer risk: A meta-analysis. Environ. Res. 2017, 156, 551-558. [CrossRef]

14. Sánchez-Bermejo, E.; Castrillo, G.; Del Llano, B.; Navarro, C.; Zarco-Fernández, S.; Martinez-Herrera, D.J.; Puerto, Y.L.-D.; Muñoz, R.; Cámara, C.; Paz-Ares, J.; et al. Natural variation in arsenate tolerance identifies an arsenate reductase in Arabidopsis thaliana. Nat. Commun. 2014, 5, 4617. [CrossRef]

15. Sharma, V.K.; Sohn, M. Aquatic arsenic: Toxicity, speciation, transformations, and remediation. Environ. Int. 2009, 35, 743-759. [CrossRef] [PubMed] 
16. Hayat, K.; Menhas, S.; Bundschuh, J.; Chaudhary, H.J. Microbial biotechnology as an emerging industrial wastewater treatment process for arsenic mitigation: A critical review. J. Clean. Prod. 2017, 151, 427-438. [CrossRef]

17. Smith, R.; Knight, R.; Fendorf, S. Overpumping leads to California groundwater arsenic threat. Nat. Commun. 2018, 9, 1-6. [CrossRef] [PubMed]

18. Thomas, D.J. Is Arsenic an Aphrodisiac? The Sociochemistry of an Element. Von William, R. Cullen. Angew. Chemie 2009, 121, 1210.

19. Moriarty, M.M.; Koch, I.; Gordon, R.A.; Reimer, K.J. Arsenic Speciation of Terrestrial Invertebrates. Environ. Sci. Technol. 2009, 43, 4818-4823. [CrossRef] [PubMed]

20. Lee, J.-J.; Kim, Y.-K.; Cho, S.-H.; Park, K.-S.; Chung, I.-J.; Cho, D.; Ryang, D.-W.; Kim, H.-J. Hemolytic Anemia as a Sequela of Arsenic Intoxication Following Long-Term Ingestion of Traditional Chinese Medicine. J. Korean Med. Sci. 2004, 19, 127-129. [CrossRef]

21. Scott, N.; Hatlelid, K.M.; MacKenzie, N.E.; Carter, D.E. Reactions of arsenic(III) and arsenic(V) species with glutathione. Chem. Res. Toxicol. 1993, 6, 102-106. [CrossRef]

22. Petrick, J.S.; Ayala-Fierro, F.; Cullen, W.R.; Carter, D.E.; Aposhian, H.V. Monomethylarsonous Acid (MMAIII) Is More Toxic Than Arsenite in Chang Human Hepatocytes. Toxicol. Appl. Pharmacol. 2000, 163, 203-207. [CrossRef]

23. Sun, H.-J.; Rathinasabapathi, B.; Wu, B.; Luo, J.; Pu, L.-P.; Ma, L.Q. Arsenic and selenium toxicity and their interactive effects in humans. Environ. Int. 2014, 69, 148-158. [CrossRef]

24. Mulvihill, M.; Tao, A.; Benjauthrit, K.; Arnold, J.; Yang, P. Surface-Enhanced Raman Spectroscopy for Trace Arsenic Detection in Contaminated Water. Angew. Chem. Int. Ed. 2008, 47, 6456-6460. [CrossRef]

25. Spanu, D.; Monticelli, D.; Rampazzi, L.; Dossi, C.; Recchia, S. Introducing Frontal Chromatography-Inductively Coupled Plasma-Mass Spectrometry as a Fast Method for Speciation Analysis: The Case of Inorganic Arsenic. Anal. Chem. 2019, 91, 13810-13817. [CrossRef]

26. Sanyal, K.; Chappa, S.; Bahadur, J.; Pandey, A.K.; Mishra, N.L. Arsenic quantification and speciation at trace levels in natural water samples by total reflection X-ray fluorescence after pre-concentration with N-methyl-d-glucamine functionalized quartz supports. J. Anal. At. Spectrom. 2020, 35, 2770-2778. [CrossRef]

27. Yang, M.; Liamtsau, V.; Fan, C.; Sylvers, K.; McGoron, A.J.; Liu, G.; Fu, F.; Cai, Y. Arsenic Speciation on Silver Nanofilms by Surface-Enhanced Raman Spectroscopy. Anal. Chem. 2019, 91, 8280-8288. [CrossRef]

28. Zhang, Q.; Minami, H.; Inoue, S.; Atsuya, I. Differential determination of trace amounts of arsenic(III) and arsenic(V) in seawater by solid sampling atomic absorption spectrometry after preconcentration by coprecipitation with a nickel-pyrrolidine dithiocarbamate complex. Anal. Chim. Acta 2004, 508, 99-105. [CrossRef]

29. Ronkart, S.N.; Laurent, V.; Carbonnelle, P.; Mabon, N.; Copin, A.; Barthélemy, J.-P. Speciation of five arsenic species (arsenite, arsenate, MMAAV, DMAAV and AsBet) in different kind of water by HPLC-ICP-MS. Chemosphere 2007, 66, 738-745. [CrossRef] [PubMed]

30. Haider, A.; Ullah, M.H.; Khan, Z.; Kabir, F.; Abedin, K. Detection of trace amount of arsenic in groundwater by laser-induced breakdown spectroscopy and adsorption. Opt. Laser Technol. 2014, 56, 299-303. [CrossRef]

31. Cai, Y. Speciation and analysis of mercury, arsenic, and selenium by atomic fluorescence spectrometry. Trends Anal. Chem. 2000, 19, 62-66. [CrossRef]

32. Bullen, J.C.; Torres-Huerta, A.; Salaün, P.; Watson, J.S.; Majumdar, S.; Vilar, R.; Weiss, D.J. Portable and rapid arsenic speciation in synthetic and natural waters by an $\mathrm{As}(\mathrm{V})$-selective chemisorbent, validated against anodic stripping voltammetry. Water Res. 2020, 175, 115650. [CrossRef] [PubMed]

33. Devi, P.; Thakur, A.; Lai, R.Y.; Saini, S.; Jain, R.; Kumar, P. Progress in the materials for optical detection of arsenic in water. Trends Anal. Chem. 2019, 110, 97-115. [CrossRef]

34. Hung, D.Q.; Nekrassova, O.; Compton, R.G. Analytical methods for inorganic arsenic in water: A review. Talanta 2004, 64, 269-277. [CrossRef]

35. Yang, T.; Zhang, X.-X.; Yang, J.-Y.; Wang, Y.-T.; Chen, M.-L. Screening arsenic(III)-binding peptide for colorimetric detection of arsenic(III) based on the peptide induced aggregation of gold nanoparticles. Talanta 2018, 177, 212-216. [CrossRef] [PubMed]

36. Memon, S.S.; Nafady, A.; Solangi, A.R.; Al-Enizi, A.M.; Shah, M.R.; Sherazi, S.T.; Memon, S.; Arain, M.; Abro, M.I.; Khattak, M.I. Sensitive and selective aggregation based colorimetric sensing of $\mathrm{Fe}^{3+}$ via interaction with acetyl salicylic acid derived gold nanoparticles. Sens. Actuators B Chem. 2018, 259, 1006-1012. [CrossRef]

37. Lakatos, M.; Matys, S.; Raff, J.; Pompe, W. Colorimetric As (V) detection based on S-layer functionalized gold nanoparticles. Talanta 2015, 144, 241-246. [CrossRef] [PubMed]

38. Kumar, P.; Bansal, V.; Kim, K.-H.; Kwon, E.E. Metal-organic frameworks (MOFs) as futuristic options for wastewater treatment. J. Ind. Eng. Chem. 2018, 62, 130-145. [CrossRef]

39. Luo, J.; Xu, F.; Hu, J.; Lin, P.; Tu, J.; Wu, X.; Hou, X. Preconcentration on metal organic framework UiO-66 for slurry sampling hydride generation-atomic fluorescence spectrometric determination of ultratrace arsenic. Microchem. J. 2017, 133, 441-447. [CrossRef]

40. Boruah, B.S.; Daimari, N.K.; Biswas, R. Functionalized silver nanoparticles as an effective medium towards trace determination of arsenic (III) in aqueous solution. Results Phys. 2019, 12, 2061-2065. [CrossRef] 
41. Boruah, B.S.; Biswas, R.; Deb, P. A green colorimetric approach towards detection of arsenic (III): A pervasive environmental pollutant. Opt. Laser Technol. 2019, 111, 825-829. [CrossRef]

42. Su, H.; Ye, Z.; Hmidi, N. High-performance iron oxide-graphene oxide nanocomposite adsorbents for arsenic removal. Colloids Surfaces A Physicochem. Eng. Asp. 2017, 522, 161-172. [CrossRef]

43. Chung, J.-Y.; Yu, S.-D.; Hong, Y.-S. Environmental Source of Arsenic Exposure. J. Prev. Med. Public Health 2014, $47,253-257$. [CrossRef]

44. Abernathy, C.O.; Thomas, D.J.; Calderon, R.L. Health Effects and Risk Assessment of Arsenic. J. Nutr. 2003, 133, 1536S-1538S. [CrossRef]

45. Brouwer, O.; Onkenhout, W.; Edelbroek, P.; De Kom, J.; De Wolff, F.; Peters, A. Increased neurotoxicity of arsenic in methylenetetrahydrofolate reductase deficiency. Clin. Neurol. Neurosurg. 1992, 94, 307-310. [CrossRef]

46. Civantos, D.P.; Rodríguez, A.L.; Aguado-Borruey, J.M.; Narvaez, J.A.J. Fulminant Malignant Arrythmia and Multiorgan Failure in Acute Arsenic Poisoning. Chest 1995, 108, 1774-1775. [CrossRef] [PubMed]

47. Tseng, W.P.; Chu, H.M.; How, S.W.; Fong, J.M.; Yeh, S.; Lin, C.S. Prevalence of Skin Cancer in an Endemic Area of Chronic Arsenicism in Taiwan2. J. Natl. Cancer Inst. 1968, 40, 453-463. [CrossRef] [PubMed]

48. Smith, A.H.; Goycolea, M.; Haque, R.; Biggs, M.L. Marked Increase in Bladder and Lung Cancer Mortality in a Region of Northern Chile Due to Arsenic in Drinking Water. Am. J. Epidemiol. 1998, 147, 660-669. [CrossRef]

49. Hopenhayn-Rich, C.; Biggs, M.L.; Fuchs, A.; Bergoglio, R.; Tello, E.E.; Nicolli, H.; Smith, A.H. Bladder Cancer Mortality Associated with Arsenic in Drinking Water in Argentina. Epidemiology 1996, 7, 117-124. [CrossRef]

50. Mazumder, D.N.G. Chronic arsenic toxicity \& human health. Indian J. Med. Res. 2008, 128, 436-447.

51. Thomas, D.J.; Styblob, M.; Linc, S. The Cellular Metabolism and Systemic Toxicity of Arsenic. Toxicol. Appl. Pharmacol. 2001, 176, 127-144. [CrossRef]

52. Cullen, W.; McBride, B.; Reglinski, J. The reduction of trimethylarsine oxide to trimethylarsine by thiols: A mechanistic model for the biological reduction of arsenicals. J. Inorg. Biochem. 1984, 21, 45-60. [CrossRef]

53. National Research Council. Arsenic in Drinking Water; The National Academies Press: Washington, DC, USA, 1999; ISBN 9780309063333.

54. W.H.O. Arsenic in Drinking-Water: Background Document for Development of WHO Guidelines for Drinking-Water Quality; World Health Organization: Geneva, Switzerland, 2003.

55. Gutzeit, H. Pharm. Zeitung 1879, 24, 263.

56. Hu, S.; Lu, J.; Jing, C. A novel colorimetric method for field arsenic speciation analysis. J. Environ. Sci. 2012, 24, 1341-1346. [CrossRef]

57. Shrivas, K.; Shankar, R.; Dewangan, K. Gold nanoparticles as a localized surface plasmon resonance based chemical sensor for on-site colorimetric detection of arsenic in water samples. Sens. Actuators B Chem. 2015, 220, 1376-1383. [CrossRef]

58. González, M.R.D.; Varela, L.G.; Bermejo-Barrera, P. Functionalized gold nanoparticles for the detection of arsenic in water. Talanta 2014, 118, 262-269. [CrossRef]

59. Forzani, E.S.; Foley, K.; Westerhoff, P.; Tao, N. Detection of arsenic in groundwater using a surface plasmon resonance sensor. Sens. Actuators B Chem. 2007, 123, 82-88. [CrossRef]

60. Krężel, A.; Leśniak, W.; Jeżowska-Bojczuk, M.; Młynarz, P.; Brasuñ, J.; Kozłowski, H.; Bal, W. Coordination of heavy metals by dithiothreitol, a commonly used thiol group protectant. J. Inorg. Biochem. 2001, 84, 77-88. [CrossRef]

61. Kalluri, J.; Arbneshi, T.; Khan, S.A.; Neely, A.; Candice, P.; Varisli, B.; Washington, M.; McAfee, S.; Robinson, B.; Banerjee, S.; et al. Use of Gold Nanoparticles in a Simple Colorimetric and Ultrasensitive Dynamic Light Scattering Assay: Selective Detection of Arsenic in Groundwater. Angew. Chem. Int. Ed. 2009, 48, 9668-9671. [CrossRef]

62. Gong, L.; Du, B.; Pan, L.; Liu, Q.; Yang, K.; Wang, W.; Zhao, H.; Wu, L.; He, Y. Colorimetric aggregation assay for arsenic(III) using gold nanoparticles. Microchim. Acta 2017, 184, 1185-1190. [CrossRef]

63. Boruah, B.S.; Daimari, N.K.; Biswas, R. Mangifera Indica Leaf Extract Mediated Gold Nanoparticles: A Novel Platform for Sensing of As(III). IEEE Sens. Lett. 2019, 3, 1-3. [CrossRef]

64. Kolya, H.; Kuila, T.; Kim, N.H.; Lee, J.H. Colorimetric/naked eye detection of arsenic ions in aqueous medium by mango flower extract: A facile and novel approach. Appl. Surf. Sci. 2020, 513, 145760. [CrossRef]

65. Zheng, B.; Li, J.; Zheng, Z.; Zhang, C.; Huang, C.; Hong, J.; Li, Y.; Wang, J. Rapid colorimetric detection of arsenic (III) by glutathione functionalized gold nanoparticles based on RGB extracting system. Opt. Laser Technol. 2021, 133, 106522. [CrossRef]

66. Paul, D.; Dutta, S.; Biswas, R. LSPR enhanced gasoline sensing with a U-bent optical fiber. J. Phys. D Appl. Phys. 2016, 49, 305104. [CrossRef]

67. Xavier, S.S.J.; Karthikeyan, C.; Kumar, G.G.; Kim, A.R.; Yoo, D.J. Colorimetric detection of melamine using $\beta$-cyclodextrinfunctionalized silver nanoparticles. Anal. Methods 2014, 6, 8165-8172. [CrossRef]

68. Divsar, F.; Habibzadeh, K.; Shariati, S.; Shahriarinour, M. Aptamer conjugated silver nanoparticles for the colorimetric detection of arsenic ions using response surface methodology. Anal. Methods 2015, 7, 4568-4576. [CrossRef]

69. Das Chakraborty, S.; Mondal, S.; Satpati, B.; Pal, U.; De, S.K.; Bhattacharya, M.; Ray, S.; Senapati, D. Wide Range Morphological Transition of Silver Nanoprisms by Selective Interaction with As(III): Tuning-Detuning of Surface Plasmon Offers To Decode the Mechanism. J. Phys. Chem. C 2019, 123, 11044-11054. [CrossRef] 
70. Siangproh, W.; Chailapakul, O.; Songsrirote, K. Simple and fast colorimetric detection of inorganic arsenic selectively adsorbed onto ferrihydrite-coated silica gel using silver nanoplates. Talanta 2016, 153, 197-202. [CrossRef]

71. Wen, S.-H.; Liang, R.-P.; Zhang, L.; Qiu, J.-D. Multimodal Assay of Arsenite Contamination in Environmental Samples with Improved Sensitivity through Stimuli-Response of Multiligands Modified Silver Nanoparticles. ACS Sustain. Chem. Eng. 2018, 6, 6223-6232. [CrossRef]

72. Kamila, S.; Mohanty, B.; Das, S.K.; Sahoo, S.; Jena, B.K. Electrochemical Sensing Platform Based on Graphene-Metal/Metal Oxide Hybrids for Detection of Metal Ions Contaminants. Fundam. Sens. Appl. 2D Mater. 2019, 301-327. [CrossRef]

73. Banerjee, S.; Kumar, N.P.; Srinivas, A.; Roy, S. Core-shell $\mathrm{Fe}_{3} \mathrm{O}_{4} @ \mathrm{Au}$ nanocomposite as dual-functional optical probe and potential removal system for arsenic (III) from Water. J. Hazard. Mater. 2019, 375, 216-223. [CrossRef]

74. Majumder, A.; Ramrakhiani, L.; Mukherjee, D.; Mishra, U.; Halder, A.; Mandal, A.K.; Ghosh, S. Green synthesis of iron oxide nanoparticles for arsenic remediation in water and sludge utilization. Clean Technol. Environ. Policy 2019, 21, 795-813. [CrossRef]

75. Liu, B.; Liu, J. DNA adsorption by magnetic iron oxide nanoparticles and its application for arsenate detection. Chem. Commun. 2014, 50, 8568-8570. [CrossRef] [PubMed]

76. Lopez, A.; Zhang, Y.; Liu, J. Tuning DNA adsorption affinity and density on metal oxide and phosphate for improved arsenate detection. J. Colloid Interface Sci. 2017, 493, 249-256. [CrossRef] [PubMed]

77. Liu, Z.; Li, G.; Xia, T.; Su, X. Ultrasensitive fluorescent nanosensor for arsenate assay and removal using oligonucleotidefunctionalized $\mathrm{CuInS}_{2}$ quantum dot@magnetic $\mathrm{Fe}_{3} \mathrm{O}_{4}$ nanoparticles composite. Sens. Actuators B Chem. 2015, 220, 1205-1211. [CrossRef]

78. Wen, S.-H.; Zhong, X.-L.; Wu, Y.-D.; Liang, R.-P.; Zhang, L.; Qiu, J.-D. Colorimetric Assay Conversion to Highly Sensitive Electrochemical Assay for Bimodal Detection of Arsenate Based on Cobalt Oxyhydroxide Nanozyme via Arsenate Absorption. Anal. Chem. 2019, 91, 6487-6497. [CrossRef] [PubMed]

79. Parlak, O.; Tiwari, A.; Turner, A.P.; Tiwari, A. Template-directed hierarchical self-assembly of graphene based hybrid structure for electrochemical biosensing. Biosens. Bioelectron. 2013, 49, 53-62. [CrossRef]

80. Shao, Y.; Wang, J.; Wu, H.; Liu, J.; Aksay, I.A.; Lin, Y. Graphene Based Electrochemical Sensors and Biosensors: A Review. Electroanalysis 2010, 22, 1027-1036. [CrossRef]

81. Compton, O.C.; Nguyen, S.T. Graphene Oxide, Highly Reduced Graphene Oxide, and Graphene: Versatile Building Blocks for Carbon-Based Materials. Small 2010, 6, 711-723. [CrossRef]

82. Pathan, S.; Jalal, M.; Prasad, S.; Bose, S. Aggregation-induced enhanced photoluminescence in magnetic graphene oxide quantum dots as a fluorescence probe for As(III) sensing. J. Mater. Chem. A 2019, 7, 8510-8520. [CrossRef]

83. Pal, S.K.; Akhtar, N.; Ghosh, S.K. Determination of arsenic in water using fluorescent ZnO quantum dots. Anal. Methods 2016, 8, 445-452. [CrossRef]

84. Butwong, N.; Srijaranai, S.; Ngeontae, W.; Burakham, R. Speciation of arsenic (III) and arsenic (V) based on quenching of CdS quantum dots fluorescence using hybrid sequential injection-stopped flow injection gas-diffusion system. Spectrochim. Acta Part A Mol. Biomol. Spectrosc. 2012, 97, 17-23. [CrossRef]

85. Al-Rekabi, S.; Kamil, Y.M.; Abu Bakar, M.; Fen, Y.; Lim, H.; Kanagesan, S.; Mahdi, M. Hydrous ferric oxide-magnetite-reduced graphene oxide nanocomposite for optical detection of arsenic using surface plasmon resonance. Opt. Laser Technol. 2019, 111, 417-423. [CrossRef]

86. Salinas, Y.; Martínez-Máñez, R.; Marcos, M.D.; Sancenón, F.; Costero, A.M.; Parra, M.; Gil, S. Optical chemosensors and reagents to detect explosives. Chem. Soc. Rev. 2012, 41, 1261-1296. [CrossRef] [PubMed]

87. Hamon, L.; Serre, C.; Devic, T.; Loiseau, T.; Millange, F.; Férey, G.; De Weireld, G. Comparative Study of Hydrogen Sulfide Adsorption in the MIL-53(Al, Cr, Fe), MIL-47(V), MIL-100(Cr), and MIL-101(Cr) Metal-Organic Frameworks at Room Temperature. J. Am. Chem. Soc. 2009, 131, 8775-8777. [CrossRef] [PubMed]

88. Taylor-Pashow, K.M.L.; Della Rocca, J.; Xie, Z.; Tran, S.; Lin, W. Postsynthetic Modifications of Iron-Carboxylate Nanoscale Metal-Organic Frameworks for Imaging and Drug Delivery. J. Am. Chem. Soc. 2009, 131, 14261-14263. [CrossRef]

89. Xie, D.; Ma, Y.; Gu, Y.; Zhou, H.; Zhang, H.; Wang, G.; Zhang, Y.; Zhao, H. Bifunctional NH2-MIL-88(Fe) metal-organic framework nanooctahedra for highly sensitive detection and efficient removal of arsenate in aqueous media. J. Mater. Chem. A 2017, 5, 23794-23804. [CrossRef]

90. Audu, C.O.; Nguyen, H.G.T.; Chang, C.-Y.; Katz, M.J.; Mao, L.; Farha, O.K.; Hupp, J.T.; Nguyen, S.T. The dual capture of AsV and AsIII by UiO-66 and analogues. Chem. Sci. 2016, 7, 6492-6498. [CrossRef]

91. Jian, M.; Wang, H.; Liu, R.; Qu, J.; Wang, H.; Zhang, X. Self-assembled one-dimensional MnO2@zeolitic imidazolate framework-8 nanostructures for highly efficient arsenite removal. Environ. Sci. Nano 2016, 3, 1186-1194. [CrossRef]

92. Lv, J.; Wang, B.; Xie, Y.-B.; Wang, P.; Shu, L.; Su, X.; Li, J.-R. Selective detection of two representative organic arsenic compounds in aqueous medium with metal-organic frameworks. Environ. Sci. Nano 2019, 6, 2759-2766. [CrossRef]

93. Canivet, J.; Fateeva, A.; Guo, Y.; Coasne, B.; Farrusseng, D. Water adsorption in MOFs: Fundamentals and applications. Chem. Soc. Rev. 2014, 43, 5594-5617. [CrossRef]

94. Boruah, B.S.; Biswas, R. Selective detection of arsenic (III) based on colorimetric approach in aqueous medium using functionalized gold nanoparticles unit. Mater. Res. Express 2018, 5, 015059. [CrossRef]

95. Yu, M.; Zhan, S.; Lv, J.; Wang, L.; Zhou, P. Colorimetric Detection of Trace Arsenic(III) in Aqueous Solution Using Arsenic Aptamer and Gold Nanoparticles. Aust. J. Chem. 2014, 67, 813-818. [CrossRef] 
96. Wu, Y.; Liu, L.; Zhan, S.; Wang, F.; Zhou, P. Ultrasensitive aptamer biosensor for arsenic(III) detection in aqueous solution based on surfactant-induced aggregation of gold nanoparticles. Analyst 2012, 137, 4171-4178. [CrossRef] [PubMed]

97. Zhang, D.; Liu, Y.; Ding, J.; Hayat, K.; Zhan, X.; Zhou, P.; Zhang, D. Label-free colorimetric assay for arsenic(III) determination based on a truncated short ssDNA and gold nanoparticles. Microchim. Acta 2021, 188, 1-9. [CrossRef] [PubMed]

98. Nguyen, N.L.T.; Park, C.Y.; Park, J.P.; Kailasa, S.K.; Park, T.J. Synergistic molecular assembly of an aptamer and surfactant on gold nanoparticles for the colorimetric detection of trace levels of $\mathrm{As}^{3+}$ ions in real samples. New J. Chem. 2018, 42, 11530-11538. [CrossRef]

99. Matsunaga, K.; Okuyama, Y.; Hirano, R.; Okabe, S.; Takahashi, M.; Satoh, H. Development of a simple analytical method to determine arsenite using a DNA aptamer and gold nanoparticles. Chemosphere 2019, 224, 538-543. [CrossRef] [PubMed]

100. Priyadarshni, N.; Nath, P.; Hanumaiah, N.; Chanda, N. DMSA-Functionalized Gold Nanorod on Paper for Colorimetric Detection and Estimation of Arsenic (III and V) Contamination in Groundwater. ACS Sustain. Chem. Eng. 2018, 6, 6264-6272. [CrossRef]

101. Ge, K.; Liu, J.; Fang, G.; Wang, P.; Zhang, D.; Wang, S. A Colorimetric Probe Based on Functionalized Gold Nanorods for Sensitive and Selective Detection of As(III) Ions. Sensors 2018, 18, 2372. [CrossRef] [PubMed]

102. Nath, P.; Priyadarshni, N.; Chanda, N. Europium-Coordinated Gold Nanoparticles on Paper for the Colorimetric Detection of Arsenic(III, V) in Aqueous Solution. ACS Appl. Nano Mater. 2018, 1, 73-81. [CrossRef]

103. Wu, Y.; Zhan, S.; Wang, F.; He, L.; Zhi, W.; Zhou, P. Cationic polymers and aptamers mediated aggregation of gold nanoparticles for the colorimetric detection of arsenic(III) in aqueous solution. Chem. Commun. 2012, 48, 4459-4461. [CrossRef]

104. Xia, N.; Shi, Y.; Zhang, R.; Zhao, F.; Liu, F.; Liu, L. Simple, rapid and label-free colorimetric assay for arsenic based on unmodified gold nanoparticles and a phytochelatin-like peptide. Anal. Methods 2012, 4, 3937-3941. [CrossRef]

105. Nath, P.; Arun, R.K.; Chanda, N. A paper based microfluidic device for the detection of arsenic using a gold nanosensor. RSC Adv. 2014, 4, 59558-59561. [CrossRef]

106. Ghodake, G.; Vassiliadis, V.S.; Choi, J.-H.; Jang, J.; Lee, D.S. Facile Synthesis of Gold Nanoparticles by Amino Acid Asparagine: Selective Sensing of Arsenic. J. Nanosci. Nanotechnol. 2015, 15, 7235-7239. [CrossRef] [PubMed]

107. Banik, D.; Manna, S.K.; Mahapatra, A.K. Recent development of chromogenic and fluorogenic chemosensors for the detection of arsenic species: Environmental and biological applications. Spectrochim. Acta Part A Mol. Biomol. Spectrosc. 2021, 246, 119047. [CrossRef] [PubMed]

108. Moussawi, R.N.; Patra, D. Modification of nanostructured $\mathrm{ZnO}$ surfaces with curcumin: Fluorescence-based sensing for arsenic and improving arsenic removal by ZnO. RSC Adv. 2016, 6, 17256-17268. [CrossRef]

109. Wang, J.; Tao, H.; Lu, T.; Wu, Y. Adsorption enhanced the oxidase-mimicking catalytic activity of octahedral-shape Mn3O4 nanoparticles as a novel colorimetric chemosensor for ultrasensitive and selective detection of arsenic. J. Colloid Interface Sci. 2021, 584, 114-124. [CrossRef]

110. Xu, X.; Wang, L.; Zou, X.; Wu, S.; Pan, J.; Li, X.; Niu, X. Highly sensitive colorimetric detection of arsenite based on reassemblyinduced oxidase-mimicking activity inhibition of dithiothreitol-capped Pd nanozyme. Sens. Actuators B Chem. 2019, $298,126876$. [CrossRef]

111. Wu, Y.; Wang, F.; Zhan, S.; Liu, L.; Luo, Y.; Zhou, P. Regulation of hemin peroxidase catalytic activity by arsenic-binding aptamers for the colorimetric detection of arsenic(III). RSC Adv. 2013, 3, 25614-25619. [CrossRef]

112. Wanga, L.; Xub, X.; Niua, X.; Pana, J. Colorimetric detection and membrane removal of arsenate by a multifunctional L-arginine modified FeOOH. Sep. Purif. Technol. 2021, 258, 118021. [CrossRef] 